\title{
Inleidende woord:
}

\section{Prof dr M J du P Beukes}

Op 31 Desember 1998 is prof Bieks Beukes se verbintenis van tien jaar met die Fakulteit Teologie (Afd A) beeindig Dit is meegebring deur vervroegde aftrede as gevolg van rasionalisasiestappe wat die Nederduitsch Hervormde Kerk verplig was om te neem. Vir elke persoon wat betrokke is by die Fakulteit Teologie (Afd A) en in die besonder vir hom en sy gesin was dit 'n hartseer geleentheid. Hy het so deel geword van die span dat 'n mens jou sy afwesigheid moeilik kon indink.

In 'n artikel deur prof T F J Dreyer word daar elders in hierdie uitgawe van Hervormde Teologiese Studies volledig verslag gelewer oor die lewe en werk van prof Beukes - daarom is hierdie 'n kort en persoonlike woord. Bieks Beukes sal altyd deur sy kollegas onthou word as 'n nougesette en harde werker. Voorleggings wat hy moes maak, memoranda wat hy moes voorberei met die oog op bespreking en verslae wat hy na die afhandeling van take of vergaderings moes opstel, is altyd nougeset en volledig gedoen. Geen werk was vir hom afskeepwerk nie. Sy werkywer het kollegas met bewondering en soms selfs met 'n bietjie jaloesie vervul.

As teoloog het Bieks Beukes hom nooit onder ekstreme groepe bevind nie. Sy opregte geloof, 'n diepe besef van sy verantwoordelikheid as dienaar van die Woord en sy besondere liefde vir die Nederduitsch Hervormde Kerk het waarskynlik die sterkste rol gespeel om aan hom 'n gematigde aanslag in sy teologiebeoefening te gee. Professor Beukes is bekend as iemand wat sterk standpunt inneem as hy daarvan oortuig is dat 'n nuwe saak meriete het. Hy het dit egter nooit op so 'n wyse gedoen dat hy kollegas of medegelowiges vervreem het nie. Sy leefstyl is altyd gekenmerk deur Christelike wellewendheid.

Ons kan hom nie 'n aangename rustyd toewens nie, want dit is nie in sy aard om uit te span nie. Wat ons hom wel graag toewens, is goeie gesondheid en lewensomstandighede wat dit vir hom en Monica moontlik sal maak om nog lank in diens van die kerk en hulle medegelowiges te staan. Dit is per slot van rekening waar hulle albei die gelukkigste is.

Prof A P B Breytenbach (Wnd) Dekaan: Teologie (Afd A) 


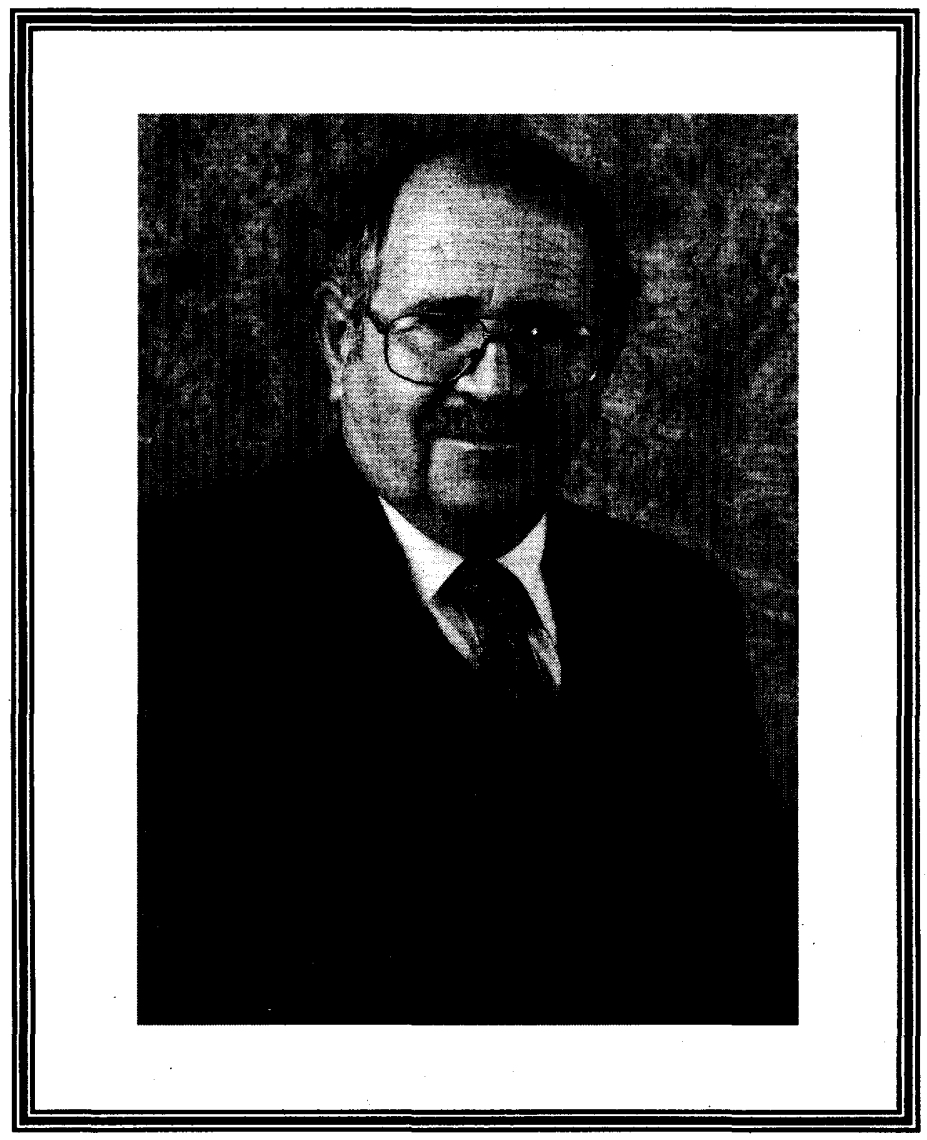

Prof $M J$ du P Beukes 


\section{Inleidende woord:}

\section{Prof dr L J S Steenkamp}

Professor Lourens Steenkamp was vir nege jaar verbonde aan die Fakulteit Teologie (Afd A), 'n tyd waarin hy deur sy innemende geaardheid en lojaliteit vir hom 'n besondere plek verwerf het in die kring van sy kollegas. Uit 'n oorsig van sy lewe en werk (vergelyk prof $\mathbf{P} \mathbf{J}$ van der Merwe se artikel elders in hierdie uitgawe) is dit duidelik dat hy 'n talentvolle persoon is wat hom oor 'n wye terrein bekwaam het.

Hy was by die Fakulteit Teologie (Afd A) nie vir een besondere vakterrein verantwoordelik nie, maar moes vir sy werksopdrag insig hê in die ensiklopediese plek van en breër verband tussen die verskillende dissiplines. Lourens Steenkamp het die vermoë gehad om vanuit 'n baie breë perspektief na probleme in die teologie te kyk. Dit het vir hom moontlikhede tot kreatiewe denke geopen. Omdat hy altyd bereid was om na ander standpunte te luister, kon hy met sy rustige geaardheid die verskille teen mekaar opweeg en uiteindelik 'n weloorwoë eie standpunt inneem.

Sy gesondheidstoestand het hom die laaste aantal jare gekortwiek sodat sy volle potensiaal nie in sy werk tot sy reg kon kom nie. Soos sy geaardheid is, het hy hierdie stryd alle'en gestry en eers op 'n baie laat stadium laat blyk dat hy 'n ernstige gesondheidsprobleem het. Sy siekte-emeritaat het saamgeval met rasionalisasiestappe by die Fakulteit. Albei hierdie sake is traumaties deur Lourens en sy gesin beleef.

Ons is dankbaar dat dit tans met hom goed gaan en dat hy baie sinvol en vrugbaar betrokke geraak het by een van die gemeentes van die kerk. Namens die redaksie wens ons hom goeie gesondheid toe en 'n geleentheid om nog vir baie jare sy talente te gebruik in diens van die kerk, want in sy diepste wese is hy dienaar van die Woord.

Prof A P B Breytenbach

(Wnd) Dekaan: Teologie (Afd A) 


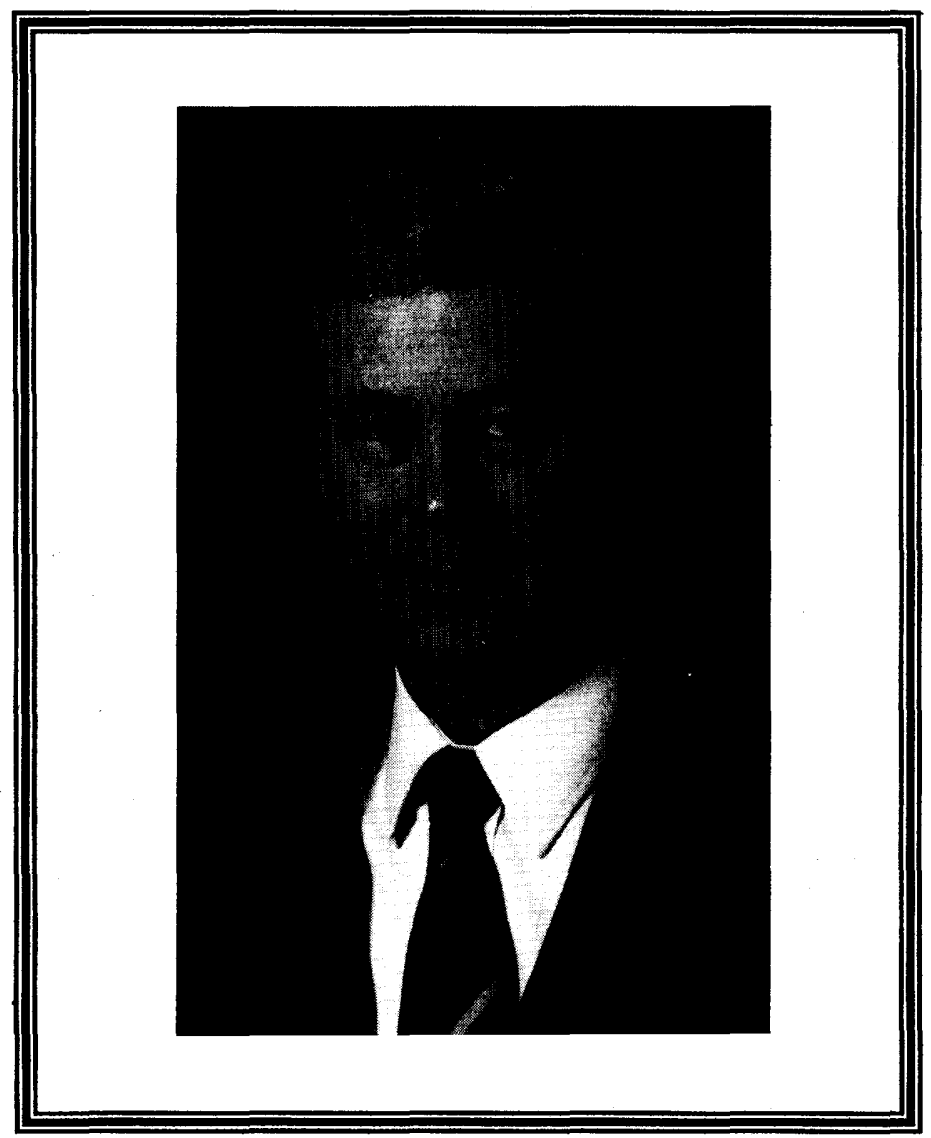

Prof dr L J S Steenkamp 